\title{
Effort To Improve Student Learning Activity Using The Google Classroom Application In Class 6
}

\author{
Jaelani Sidik \\ SDN Kajenengan 02 \\ Jaelanisidik.gmpi@gmail.com
}

\section{Articel history}

accepted 01/11/2020

approved 08/11/2020

published 15/11/2020

\begin{abstract}
This study aims to improve student learning activeness in grade 6 using the google classroom application. This research is a classroom action research conducted in 3 cycles. The implementation of each cycle consists of preparation, implementation, observation and reflection. The classroom action research was carried out in grade 6 SDN Kajenengan 02. The study was conducted using the observation sheet using application and student questionnaires on learning activeness. The results of the research in cycle 1 showed that the response to activeness was $84.5 \%$ and in cycle 2 it was $91.9 \%$, and there was an increase again in cycle 3, namely 93.3\%. From these results it can be concluded that google classroom can improve the learning activeness of grade 6 students at SDN Kajenengan 02.
\end{abstract}

Keywords: google classroom, learning activeness, classroom action research

\begin{abstract}
Abstrak
Penelitian ini bertujuan untuk meningkatkan keaktifan belajar siswa di kelas 6 menggunakan aplikasi google classroom. Penelitian yang dilakukan merupakan penelitian tindakan kelas yang dilaksanakan dalam 3 siklus. Dalam pelaksanaan setiap siklus tersiri dari kegiatan persiapan, pelaksanaan, observasi, dan refleksi. Penelitian tindak kelas tersebut dilaksanakan pada kelas 6 SDN Kajenengan 02. Penelitian dilakukan menggunakan lembar observasi penggunaan apliaksasi dan angket siswa terhadap keaktifan belajar. Hasil penelitian pada siklus 1 bahwa respon keaktifan sebesar $84,5 \%$ dan pada siklus 2 sebesar $91,9 \%$, dan mengalami peningkatan kembali pada siklus 3 yaitu 93,3\%. Dari hasil tersebut dapat disimpulkan bahwa google classroom dapat meningkatkan keaktifan belajar siswa kelas 6 SDN kajenengan 02.
\end{abstract}

Kata kunci : google classroom, keaktifan belajar, penelitian tindak kelas

Social, Humanities, and Education Studies (SHEs): Conference Series p-ISSN 2620-9284 https://jurnal.uns.ac.id/shes

e-ISSN 2620-9292 


\section{PENDAHULUAN}

Di masa pandemi covid-19, pembelajaran daring adalah alternatif paling tepat untuk kegiatan belajar mengajar. Kebijakan Pada Masa Pandemi Belajar dari Rumah melalui pembelajaran daring/jarak jauh dilaksanakan untuk memberikan pengalaman belajar yang bermakna bagi peserta didik, tanpa terbebani tuntutan menuntaskan seluruh capaian kurikulum untuk kenaikan kelas maupun kelulusan. Namun pembelajaran daring adalah hal yang baru bagi siswa dan juga guru di sekolah. Berbagai masalah pun timbul seiring berjalannya pembelajaran daring. Beberapa permasalahan yang muncul anatara lain adalah : 1) Pembelajaran daring tidak maksimal hanya menggunakan media whatsapp. 2) Banyak siswa yang tidak aktif dan tidak mengerjakan evaluasi pembelajaran. 3) Masih banyak siswa yang tidak mengumpulkan tugas daring ynag diberikan guru. 4) Rendahnya partisipasi aktif dari orang tua dalam mendampingi siswa ketika kegiatan pembelajaran daring.

Menurut Annurahman (2009: 119) menyatakan keaktifan siswa dalam belajar merupakan persoalan penting dan mendasar yang harus dipahami, dan dikembangkan setiap guru dalam proses pembelajaran. Sehingga keaktifan siswa perlu digali dari potensi-potensinya, yang mereka aktualisasikan melalui aktifitasnya untuk mencapai tujuan pembelajaran. Menurut Sari, D.P., \& Rahardi (2013) menjelaskan bahwa keaktifan dapat meningkatkan hasil belajar. Berdasarkan penelitian dapat disimpulkan bahwa meningkatkan keaktifan siswa dapat dilakukan dengan 5 tahap, yaitu presentasi kelas, (tim) kerjasama kelompok, (game) presentasi hasil diskusi, (turnamen) mengerjakan soal kuis, (penghargaan) hasil nilai. Menurut Mustari \& Irianto (2016) menarik kesimpulan bahwa aktivitas belajar siswa mengalami peningkatan pada pembelajaran. Hal tersebut ditunjukan dengan meningkatnya aktivitas siswa ketika diskusi kelompok, yaitu pada saat mengemukakan pendapat dan kerjasama.

Pembelajaran daring strategi untuk meningkatkan keaktifan siswa adalah melalui aplikasi pembelajaran. Salah satu media teknologi yang sering digunakan saat ini adalah aplikasi pada telepon genggam/ponsel. Hasil penelitian Gheytasi et al., (2015) menunjukan bahwa siswa yang banyak berinteraksi dengan aplikasi di telepon genggam lebih mudah memahami isi teks bacaan. Banyak berbagai macam media pembelajaran yang ada namun belum digunakan guru secara maksimal. Salah satunya adalah penggunaan media aplikasi google classroom dapat dimanfaatkan sebagai media pembelajaran untuk membantu meningkatkan hasil belajar siswa. Desain dari Google Classroom sudah tidak asing lagi bagi siswa karena mereka sudah menggunakan beberapa produk dari Google via akun Google Apps (Izenstark dan Leahy, 2015).

Dari kajian teori yang diungkapkan oleh para ahli, selanjutnya akan diguanakan dalam penelitian yang dilakukan di kelas 6 . Berdasarkan kajianteori tersebut dapat disimpulkan rumusan masalah pada penelitain sebagai berikut, pertama bagaimana penggunakan google classroom dapat meningkatkan keaktifan belajar siswa kelas 6 SDN Kajenengan 02. Kedua apakah google classroom dapat meningkatkan keaktifan belajar siswa kelas 6 SDN Kajenengan 02.

Dengan demikian, tujuan dari penelitian ini adalah untuk mengetahui apakah penggunaan aplikasi google classroom ini dapat meningkatkan hasil belajar matematika. Sehingga hasil penelitian ini juga dapat diketahui hasil peningkatan kemampuan melalui tes yang diberikan. Adapun rumusan masalah penelitian adalah bagaimana penggunaan aplikasi google classroom dapat meningkatkan hasil belajar.

\section{METODE}

Penelitian yang dilakukan merupakan penelitian tindakan kelas yang dilaksanakan dalam 3 siklus. Dalam pelaksanaan setiap siklus tersiri dari kegiatan 
persiapan, pelaksanaan, observasi, dan refleksi. Objek dari penelitian tindakan kelas tersebut adalah siswa kelas 6 SDN Kajenengan 02 Kecamatan Bojong Kabupaten Tegal. Siswa tersbut berjumalh 25 siswa. Pelaksanaan penelitian antara bulan oktober sampai bulan November semester satu tahun ajaran 2020/2021. Dalam penelitian ini teknik pengumpulan data yang digunakan melalui hasil observasi penggunaan aplikasi google classroomoleh teman sejawat dan lembar angket respon siswa terhadap penggunaan aplikasi google classroom. Teknik analisis data meliputi reduksi data, penyajian data, dan penarikan kesimpulan.

\section{HASIL DAN PEMBAHASAN}

Pelaksanan pembelajaran dalam penelitian dilakukan mulai dari kegiatan pembukan, kegiatan inti dan kegiatan penutup. Dalam pembelajaran lebih kami tekankan dalam penggunaan aplikasi google classroom. Dalam setiap siklus terjadi peningkatan keaktifan siswa dalam kegiatan pembelajaran.

Berdasarkan analisis hasil penelitian yang telah diuraikan maka pembahasan pada penelitian ini sebagai berikut.

\section{Penerapan Penggunaan Aplikasi google classroom}

Berdasarkan penelitian tindakan kelas yang sudah dilakukan sesuai dengan langkah-langkah kahoot mengalami peningkatan. Peningkatan dapat dilihat pada tabel berikut.

Tabel 1. Hasil observasi langkah-langkah penggunaan aplikasi google classroom

\begin{tabular}{ccccc}
\hline No & \multicolumn{1}{c}{ Aspek yang Diamati } & Siklus 1 & Siklus 2 & Siklus 3 \\
\hline 1 & $\begin{array}{l}\text { Guru meminta peserta didik untuk menyiapkan smartphone } \\
\text { guna masuk ke aplikasi google classroom. }\end{array}$ & 1 & 1 & 1 \\
2 & $\begin{array}{l}\text { Guru membagikan link google classroom kepada peserta } \\
\text { didik untuk masuk dalam menu undang siswa. }\end{array}$ & 1 & 1 & 1 \\
2 & $\begin{array}{l}\text { Guru memberikan petunjuk penggunaan google classroom } \\
\text { dengan jelas }\end{array}$ & 1 & 1 & 1 \\
$3 \quad \begin{array}{l}\text { Guru memeriksa kesiapan fisik maupun psikis peserta didik } \\
\text { sebelum melalui google classroom. }\end{array}$ & 0 & 0 & 1 \\
$4 \quad \begin{array}{l}\text { Guru mempersilahkan peserta didik memasuki google } \\
\text { classroom }\end{array}$ & 1 & 1 & 1 \\
5 & $\begin{array}{l}\text { Guru membimbing peserta didik dalam menegelola alikasi } \\
\text { google classroom }\end{array}$ & 1 & 1 & 1 \\
$6 \quad \begin{array}{l}\text { Guru memberi reward terhadap peserta didik yang telah } \\
\text { menginput tugas pada google classroom } \\
\text { Guru memberi dorongan / motivasi terhadap peserta didik } \\
\text { yang belum tepat dalam menjawab pertanyaan yang } \\
\text { disajikan di google classroom }\end{array}$ & 1 & 1 & 1 \\
8 & $\begin{array}{l}\text { Guru menjelaskan perolehan nilai tugas yang telah } \\
\text { dikerjakan }\end{array}$ & 1 & 1 & 1 \\
\hline Jumlah & 8 & 9 & 10 \\
\hline
\end{tabular}


Berdasarkan data hasil observasi penggunaan aplikasi google classroom di atas, dapat disimpulkan bahwa peneliti mengalami peningkatan dalam menggunakan aplikasi google classroom. Hal itu sejalan dengan pernyataan Data hasil observasi tersebut dilakukan oleh teman sejawat yaitu kepala sekolah

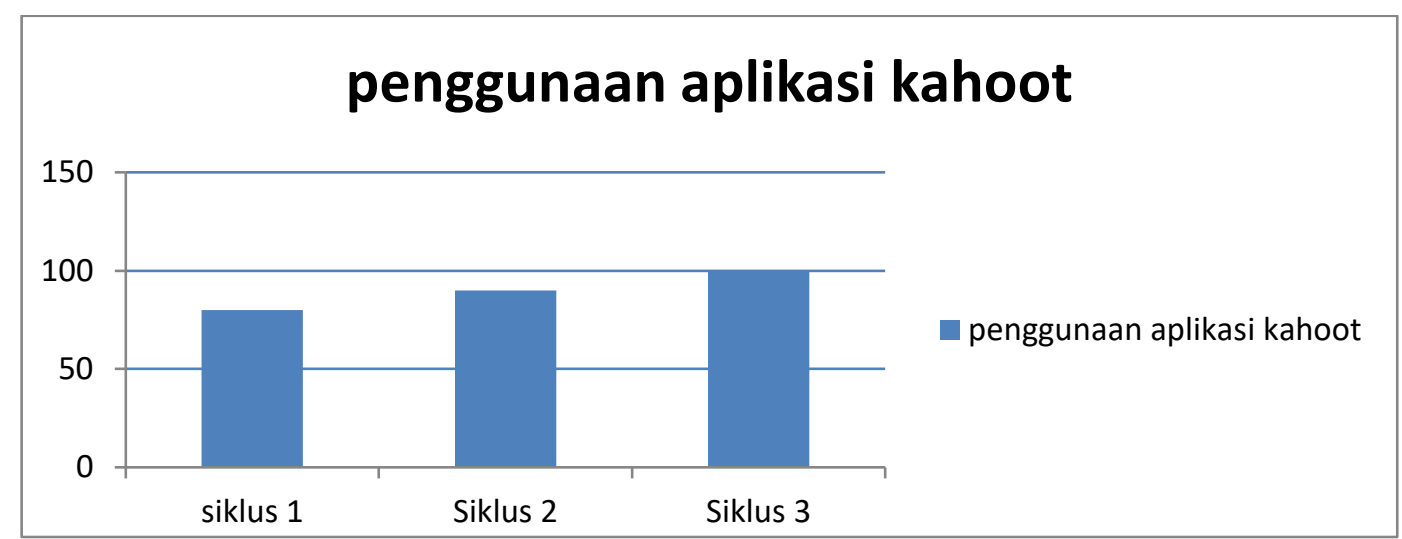

Gambar 1. Diagram hasil observasi langkah-langkah pelaksanakan google classroom pada pembelajaran

2. Penerapan keaktifan belajar siswa

Berdasarkan penelitian tindakan kelas yang sudah dilakukan bahwa keaktifan belajar siswa kelas 6 SD Negeri Kajennegan 02 dengan penggunaan aplikasi google classroom dapat meningkat. Peningkatan kektifan belajar siswa dapat dilihat pada table rekapitulasi respon siswa berikut.

Tabel 2. Rekapitulasi hasil angket respon siswa dengan menggunakan aplikasi google classroom

\begin{tabular}{ccccccccc}
\hline \multirow{2}{*}{$\begin{array}{c}\text { Rentang } \\
\text { Nilai }\end{array}$} & $\begin{array}{c}\text { Tingkat } \\
\text { keaktifan }\end{array}$ & \multicolumn{2}{c}{ SIKLUS I } & Presentase & $f$ & Presentase & $f$ & Persentase \\
\cline { 3 - 8 } & & $f$ & SIKLUS II & \multicolumn{2}{c}{ SIKLUS II } \\
\hline $86-100$ & Tinggi & 12 & $48 \%$ & 20 & $80 \%$ & 24 & $96 \%$ \\
$70-85$ & Sedang & 8 & $32 \%$ & 5 & $20 \%$ & 1 & $4 \%$ \\
$<70$ & Rendah & 5 & $20 \%$ & - & - & - & - \\
\hline
\end{tabular}

Pada penelitian siklus 1 terdapat 12 peserta didik yang motivasinya tinggi dengan presentase $48 \%$, kemudian ada 8 peserta didik yang motivasinya sedang dengan presentase $32 \%$, sedangkan 5 peserta didik yang motivasinya rendah dengan presentase $20 \%$. Sedangkan pada penelitian siklus 2 mengalami peningkatan yaitu terdapat 20 peserta didik yang motivasinya tinggi dengan presentase $80 \%$, dan 5 peserta didik yang motivasinya sedang dengan presentase $20 \%$.kemudian pada siklus 3 juga mengalami peningkatan yaitu terdapat 24 peserta didik yang motivasinya tinggi dengan presentase $96 \%$, dan 1 peserta didik yang motivasinya sedang dengan presentase 4\%. Peningkatan motivasi belajar dengan peggunaan kahoot sesuai dengan kajian penelitian yang relevan yang dilakukan oleh Abdul Barir Hakim(2019) 
dalam penelitian yang berjudul "efektifitas penggunaan e-learning model, google classroom dan edmodo" dengan hasil bahwa siswa lebih bersemangat dalam belajar dan aktif dalam menggunakan media pembelajaran google classroom.

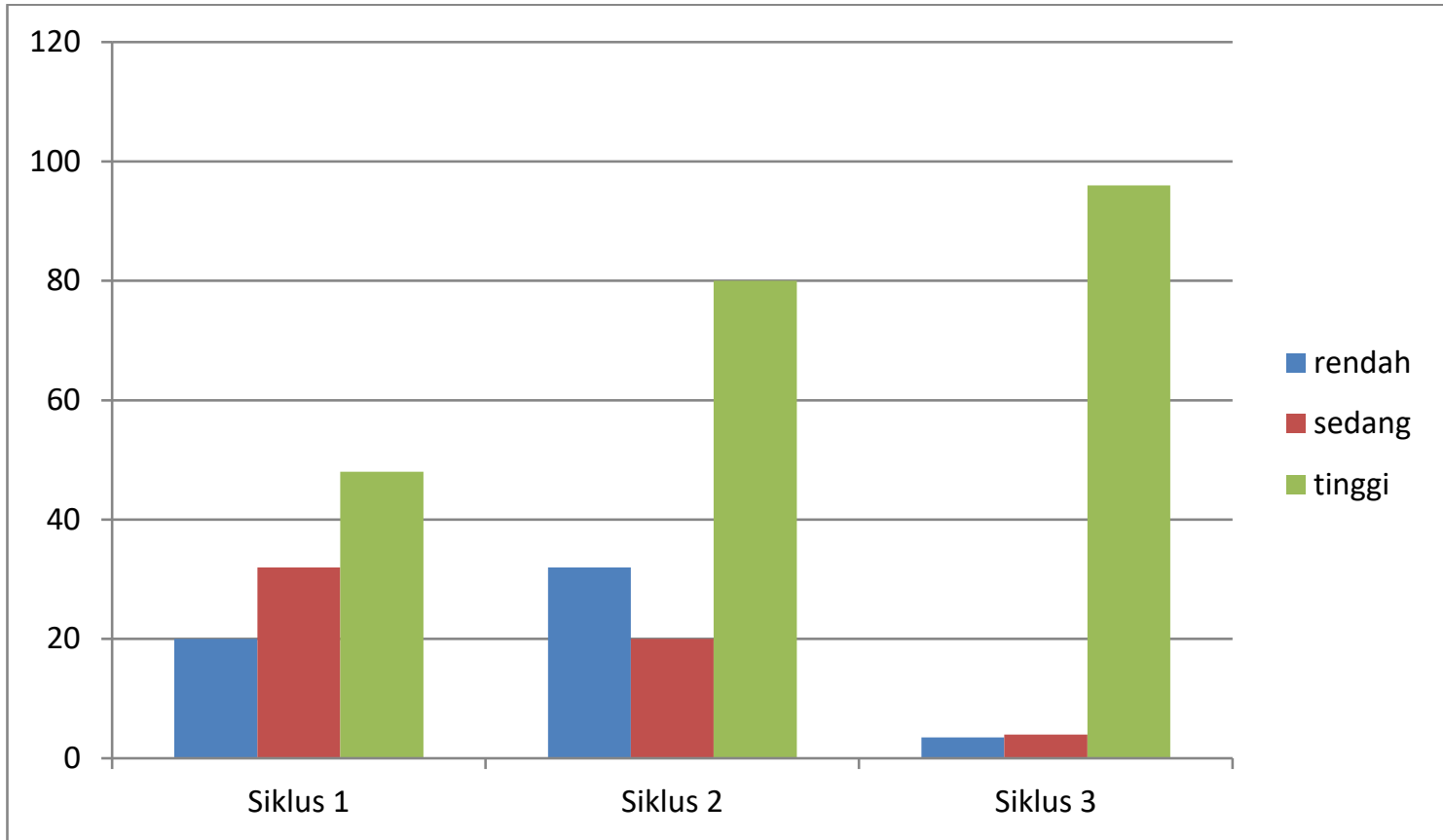

Gambar. 2 Rekapitulasi hasil angket respon siswa dengan menggunakan aplikasi google classroom

\section{SIMPULAN}

Berdasarkan hasil penelitian tindakan kelas yang sudah dilakukan dapat disimpulkan bahwa dengan melakukan langkah-langkah penggunan aplikasi ggogle classroom yang meliputi Guru meminta peserta didik untuk menyiapkan smartphone guna masuk ke aplikasi google classroom, Guru membagikan link google classroom kepada peserta didik untuk masuk dalam menu undang siswa, Guru memberikan petunjuk penggunaan google classroom dengan jela, Guru memeriksa kesiapan fisik maupun psikis peserta didik sebelum melalui google classroom, Guru mempersilahkan peserta didik memasuki google classroom, Guru membimbing peserta didik dalam menegelola alikasi google classroom, Guru memberi reward terhadap peserta didik yang telah menginput tugas pada google classroom, Guru memberi dorongan / motivasi terhadap peserta didik yang belum tepat dalam menjawab pertanyaan yang disajikan di google classroom, Guru menjelaskan perolehan nilai tugas yang telah dikerjakan, dapat meningkatkan keaktifan belajar siswa pada kelas 6 SDN Kajenengan 02. Diharapkan untuk penggunaan aplikasi google classroom pada pembelajaran daring selalu dilaksanakan di SDN Kajenengan 02. Dan penggunaan aplikasi yang lebih bervariatif sehingga akan meningkatkan kualits pendidikan di SDN Kajenengan 02 pada khususnya. 


\section{DAFTAR PUSTAKA}

Depdiknas.2003.Undang-undang RINo.20 tahun 2003 tentang Sistem Pendidikan Nasional.

Hardiyana, Andri. 2015. Implementasi Google Classroom sebagai Alternatif dalam Meningkatkan Mutu Pembelajaran di Sekolah. Karya Tulis IImiah, Cirebon : SMA Negeri 1 Losari.

Sari, Denis Purnama. 2013. "Peningkatan Keaktifan dan Hasil Belajar Siswa Kelas XI IPS 2 SMA Negeri Turen Pada Pokok Bahasan Turunan dengan Pembelajaran Kooperatif Tipe Teams Games Turnament (TGT). Jurnal Jurusan MIPA Universitas Negeri Malang

Diemas P.P Dan Rina Harimurti. 2017. "Pengaruh Penerapan Tools Google Clasroom Pada Model Pembelajaran Project Based Learning Terhadap Hasil Belajar Siswa." Jurnal IT-Edu 2(1), 59-67.

https://www.pelajaran.co.id/2019/15/pengertian-ptk-tujuan-karakteristik- $\quad$ prinsiplangkah-dan-model-penelitian-tindakan-kelas-ptk.html (diakses tanggal 7 Oktober 2020 pukul 14:21 WIB)

Auliyana, Siti. 2015. "Penerapan Google Classroom Sebagai Media Pembelejaran pada Pelajaran Kimia SMK Negeri 2 Temanggung." Skripsi, Fakultas Teknologi Informasi, Universitas Kristen Satya Wacana, Salatiga.

Izenstark, Amanda and Katie L. Leahy. 2015. "Google Classroom for Librarians : Features and Opportunities." Library $\mathrm{Hi}$ Tech News 32 (9):1-3. https://doi.org/10.1108/LHTN-05-2015-0039 